\title{
Hasidism under the Influence of Hesychasm and Sufism: Baal Shem Tov - A Jewish Sufi and Hesychast?
}

\author{
Bülent Şenay \\ Doç. Dr., Bursa Uludağ Üniversitesi, İlahiyat Fakültesi, Dinler Tarihi Ana Bilim Dalı \\ Bursa/Türkiye \\ bshanay@uludag.edu.tr \\ https://orcid.org/0000-0002-4683-3417
}

\begin{abstract}
This paper is an attempt to bring to light the manner in which Hasidism emerged inside the Jewish tradition not just as a climax of previous mystical developments, but also under the direct influence of Hesychasm and Sufism. All of these types of mysticism seem to have met in $18^{\text {th }}$ century Moldova (the Bogdan province of the Ottoman Empire), in the new and revolutionary outlook of an unusual man called Israel ben Eliezer, also known as Baal Shem Tov ("the master of the good name"), who appears to have been born there, although he started preaching only after moving to Poland. Regardless of how much of his story as we know it today is true or legendary, his imprint on the evolution of the oldest monotheistic religion is undeniable and still awaits further scrutiny, despite the number of works written about him so far. Considering that the movement he set in motion, which started as an offshoot of mainstream Judaism meant to solve a religious crisis by straying partially away from the established religious practices, proposing to worship God not just through prayer but also through storytelling, music and dance, and to replace the rabbi with the tzaddik (righteous/wise man), has nowadays ended up by being the most ultra-Orthodox form of Jewishness, it is interesting to fathom the extent to which it was infused by Islamic ideas. The article therefore also takes into account the Islamic influence on the evolution of Jewish mysticism, from the emergence of Islam until today's Jewish liturgical and meditative practice.
\end{abstract}

Keywords: History of Religions, Hasidism, Sufism, Hesychasm, Baal Shem Tov, Moldova, Bucovina

Geliş Tarihi/Received Date: 02.03.2021

Kabul Tarihi/Accepted Date: 16.03.2021

Araştırma Makalesi/Research Article

Atıf/Citation: Şenay, Bülent. "Hasidism under the Influence of Hesychasm and Sufism: Baal Shem Tov A Jewish Sufi and Hesychast?”. Uludağ Üniversitesi İlahiyat Fakültesi Dergisi 30/1 (Haziran 2021), 57-77. https://doi.org/10.51447/uluifd.889672

Uludağ Üniversitesi İlahiyat Fakültesi Dergisi 30/1 (Haziran 2021) 


\section{Tasavvuf ve Hesikazm'in Etkisinde Hasidizm: Baal Shem Tov - Bir Yahudi Sufi midir yoksa Hesikast mıdır?}

Öz: Bu makale, Hasidizm'in Yahudi geleneğinde sadece önceki mistik gelişmelerin doruk noktası olarak değil, aynı zamanda Hesikazm ve Tasavvufun bazı türlerini doğrudan etkisi altında ortaya çıkma tarzını gün ışığına çıkarmayı amaçlayan bir çalışmadır. Bütün bu tasavvuf türleri, 18. yüzyılda Moldova'da (Osmanlı İmparatorluğu'nun Boğdan eyaleti), vaaz vermeye ancak Polonya'ya taşındıktan sonra başlamasına rağmen yine de orada doğduğu kabul edilen İsrail ben Eliezer adında, Baal Shem Tov (ismi güzel efendi) olarak da bilinen sıradışı bir adamın yeni ve inkılabi kabul edilebilecek düşüncelerinde harmanlanmış görünüyordu. Bugün bildiğimiz hikâyesinin ne kadarının gerçek ya da efsanevi olduğuna bakılmaksızın, kadim tek tanrılı dinler geleneği içerisinde önemli bir 'hikâye' olduğu inkâr edilemeyeceği gibi onun hakkında şimdiye kadar yazılmış eserlerin çokluğuna rağmen hala daha fazla araştırmaya da açı olduğu söylenebilir. Tov'un, ana akım Yahudiliğin bir uzantısı olarak başlattığı bu hareketin, dini bir krizi yerleşik dini uygulamalardan kısmen uzaklaşarak çözmeyi amaçladı̆̆ını düşünerek, Tanrı’ya sadece dua yoluyla değil, aynı zamanda kıssa anlatımı, müzik ve dans/zikr yoluyla da ibadet etmeyi, haham'ı tzaddik (sadık/bilge kişi) ile değiştirmeyi önermiş olmasına rağmen, günümüzde Yahudiliğin en ultra-Ortodoks formu haline gelişinde İslami fikirlerin ne ölçüde aşılandığını incelemek ilginç olabilir. Bu makale, o nedenle, İslam'ın ortaya çıkışından günümüz Yahudi ayin ve ibadetlerine kadar Yahudi mistisizmin gelişimi üzerindeki İslam’ın etkisini hesaba katan bir çalışmadır.

Anahtar Kelimeler: Dinler Tarihi, Hasidilik, Tasavvuf, Hesikazm, Baal Shem Tov, Moldova, Bukovina.

\section{Introduction}

An important aspect to be sought in the study of the history of religions is the connection and cross-influence between the various traditions that meet in a given place. Every time a new trend emerges in an established religious setting, tracing back its roots in the different sources that have concurred to make it happen is a fascinating discovery journey in itself.

As Shaul Magid, who is known for his works on Jewish mysticism, and particularly on Hasidism, underlines:

"The richness of a textual tradition can become visible when refracted through a prism of ideas from a competing tradition without apparent historical influence or confluence. Scrutinizing inherited distinctions, for example those between Judaism and Christianity, is a fruitful way of revisiting Jewish mystical texts that have characteristics challenging to traditional received interpretations. [...] the best way to examine difference is 
through sameness, and sameness is best articulated through shared nomenclature."

On the other hand, the about eight centuries spent by various parts of Spain under Muslim influence (from the $8^{\text {th }}$ to the $15^{\text {th }}$ century), which are often called "the golden age" and viewed as a "paradise lost", a model of coexistence (even if the life of its inhabitants was not always easy), facilitated extensive interactions between Jewish and Muslim scholars and thinkers, which resulted in a strong Muslim influence on the Jewish tradition of interpretation and particularly mystical culture. In the words of Tom Block, a visual artist interested in the mystical intermingling between various traditions including the Jewish and Muslim ones:

"[...] The development of medieval Judaism and even contemporary Jewish practice cannot be fully understood without acknowledging and comprehending the influence of the one (Islamic mysticism) upon the other (Jewish mysticism). The term "Jewish-Sufi" honors this fraternity."

This study is therefore an attempt to shed some light on the manner in which Hasidism emerged inside the Jewish tradition not just as a climax of previous mystical developments, but also under the direct influence of Hesychasm and Sufism. All of these types of mysticism seem to have met in $18^{\text {th }}$ century Moldova, in the new and revolutionary outlook of an unusual man called Israel ben Eliezer, also known as Baal Shem Tov (the master of the good name). Regardless of how much of his story as we know it today is true or legendary, his imprint on the evolution of the oldest monotheistic religion is undeniable and still awaits further scrutiny, despite the number of works written about him so far.

\section{Baal Shem Tov and Hasidism}

In the Foreword to his 1932 book on Baal Shem Tov, Meyer Levin, who is known for his works on Jewish life and history, tells us that:

"Two hundred years ago, in a remote hut in the Carpathian Mountains, there lived a wonderworker named Rabbi Israel. Some now say that he never existed; the like has been said of King Arthur and of Jesus Christ; their legends remain with us. Some say that Israel was never a rabbi, but rather an unlearned peasant who took authority unto himself. It is told that even as a

1 Shaul Magid, Hasidism Incarnate, Hasidism, Christianity and the Construction of Modern Judaism (Stanford: Stanford University Press, 2015), 1.

2 Among what he calls "Jewish-Sufis" Block mentions Bahya ibn Pakuda ( $11^{\text {th }}$ century), Moses Maimonides ( $12^{\text {th }}$ century), Abraham Abulafia ( $13^{\text {th }}$ century), Isaac of Acre (1 $13^{\text {th }}$ century), Hayyim Vital ( $16^{\text {th }}$ century).

3 Tom Block, Shalom Salaam: A Story of a Mystical Fraternity (Louisville: Fons Vitae, 2010), X. 
child he deserted the village schoolroom to run into the woods where he learned the speech of animals and birds, of trees, stones, and flowers.

A grown man, he knew all the secret mysteries of Cabbala; but he refused to lead the stifled life of the synagogue scholar, turned his back upon the rabbinical bickerings and pin-point disputes over minutae of the law, and withdrew to the mountains, where he earned his livelihood as a lime-burner, and where he would wander alone, sometimes for many days, absorbed in his strange reflections.

When Israel came down from the mountains to Medzibuz it was to teach men to live with abounding joy, for joy in every living thing, he said, is the highest form of worship. The woods were holy, and the fields, every stone and blade of grass contained a spark of the living Soul; every act of living: breathing, eating, walking should be accomplished with fervor, joy, ecstasy, for every act spoke to God. Scholars who had passed their pale youth huddled over tomes of the law lifted their heads and for the first time saw the sky; he drew them out of the murky synagogue into the open fields; there, too, he said, God would hear them."4

Although for many years scholars have repeated one after the other that Israel ben Eliezer, Baal Shem Tov, the founder of Hasidism, was born around 1698 in Okup, today Ukraine but at that time Poland, Moshe Idel, one of the most important specialists in the Kabbalah and Hasidism, has rightfully argued in an article published in 2008 and republished in 2011 that not only is there no documentary evidence to support such claim, but on the contrary, there is enough proof in available sources that in fact he was born in Moldova (or Great Wallachia as it was sometimes called in $18^{\text {th }}$ century local sources), very likely in the Province of Bucovina, on what was a border area at the time. ${ }^{5}$ This "forces us to contemplate some profound but rarely considered religious influences on the emergence of Hasidism," because it may explain some of the innovative ideas that Baal Shem Tov brought into the Jewish religious practice once he started preaching in Poland. Furthermore, one legend has it that before Baal Shem Tov was born his father was kidnapped by Tatars and taken as a slave to a distant land, from where he was able

\footnotetext{
4 Meyer Levin, The Golden Mountain, Marvelous Tales of Rabbi Israel Baal Shem and of his Great-grandson, Rabbi Nachman, Retold from Hebrew, Yiddish and German Sources (New York: Jonathan Cape \& Robert Ballou, 1932), IX.

5 Moshe Idel, "In the State of Walachia Near the Border - Or Was the Besht Born in Okopy?", Eurolimes 5 (2008), 14-20, and respectively Moshe Idel, "R. Israel Ba'al Shem Tov 'In the State of Walachia" Holy Dissent, Jewish and Christian Mystics in Eastern Europe, ed. Glenn Dynner (Detroit: Wayne State University Press, 2011), 69-103.

6 Idel, "R. Israel Ba'al Shem Tov 'In the State of Walachia", 69.
} 
to return after a long and adventurous life. ${ }^{7}$ This, too, is a relevant piece of information because it speaks of an additional possible interesting connection with Muslim sources.

In trying to define it, Moshe Idel says

"to paraphrase a recent definition of the Sufi philosophy of illumination, Hasidism is a unique synthesis of primordial themes and concepts, traditions as old and primal as those of the paleolithic age and as late and refined as those of Renaissance and early modern religiosity." ${ }^{8}$

Often described as a typical revivalist movement, "an attempt to preserve those elements of Kabbalism which were capable of evoking a popular response, but stripped of its messianic flavor" as Gershom Scholem, the professor who turned the study of the Kabbalah into an academic subject, puts it, ${ }^{9}$ Hasidism emerged, not by chance, in the aftermath and under the influence of Sabbateanism, a mystical trend born in the Ottoman Empire in 1665, when Shabbatai Zvi (1626-1676), a Kabbalist from Smyrna, declared himself the Messiah and announced the arrival of a new cosmic era, in which a new Torah would apply, with all its implications. ${ }^{10}$ Although he seems to have been an exalted man, his ideas did not come from nowhere. They had solid base in previous kabbalistic theories such as the existence of a succession of eons (not unlike the similar outlooks of other ancient civilizations, which spoke of yugas [Hindus] or the end of the world [Mayas]), hence the possible arrival of a new spiritual world order. ${ }^{11}$ That is precisely why these ideas were quickly embraced, particularly as they gave hope to the Jewish communities in Poland, affected by the Cossack massacres of $1648-1649,{ }^{12}$ which also spilled over into Moldova, when the Cossack leader, Bogdan Chmelnitsky (ca 1595-1657), forcefully married his son Timush to Ruxandra, the daughter of the Moldovan Prince, Vasile Lupu (1595-1661), and tortured and killed a number of local Jews as a wedding present. ${ }^{13}$ They also gave hope to the Christians who were awaiting the second coming of Jesus in $1666 .{ }^{14}$ All of these led to a massive migration, both Jewish and

7 Idel, "R. Israel Ba'al Shem Tov 'In the State of Walachia”, 72.

8 Moshe Idel, Hasidism between Ecstasy and Magic (Albany: State University of New York Press, 1995), 225.

9 Gershom Scholem, Major Trends in Jewish Mysticism (New York: Schocken Books, 1995), 337.

10 Aryeh Kaplan, Mediation and Kabbalah (Boston: WeiserBooks, 1985), 266-267.

11 Gershom Scholem, On the Kabbalah and its Symbolism (New York: Schocken Books, 1965), 78.

12 Kaplan, Mediation and Kabbalah, 267.

13 Cătălin Pena, "Grozăviile ar fi albit părul pruncilor când moldovenii s-au schimbat toți în tâlhari răzvrătiți,” Evenimentul Istoric (Accessed 9 July 2020).

14 For detailed information on this prediction see David Brady, 1666, The Year of the Beast (Manchester: John Rylands University Library of Manchester, 1979). 
Christian, towards the Holy Land that started worrying Sultan Mehmet IV. ${ }^{15}$ While the enterprise ended in apostasy and disaster, as given the choice between conversion to Islam or death Zvi opted for the former, (again based on a previous kabbalistic theory which claimed that one needed to enter the realm of evil in order to be able to fight it successfully, thus justifying the superficial acceptance of another religion in view of the true redemption), ${ }^{16}$ it did leave a significant mark on the ulterior evolution of Jewish mystical thought, of which Hasidism was an important, albeit not the only, part.

It is also relevant to recall that the context in which Hasidism emerged was characterized by poverty and deprivation. Jewish communities in Eastern Europe had reached to a point where they literally lacked the financial means to hire rabbis and organize "heders," schools for boys to learn the Torah in preparation for their Bar Mitzvah (coming of age). In these dire circumstances Baal Shem Tov came up with a salutary solution: he argued that there was no need for a thorough study of the Talmud (or for Lurianic meditations for that matter) in order to get close to God; one could worship God by simply seeing Him in everything and by practicing a simple and sincere devotion through prayer, but also through song, dance and storytelling. ${ }^{17}$ Baal Shem Tov is thus said to have tried to express kabbalistic ideas in the psychological terms of ordinary human experience, giving mysticism a "social function." 18 He also determined the emergence of a new type of spiritual leader: instead of the erudite Talmudist he proposed the model of the Tzaddik, the wise man who could set an example of righteousness and gather people around him. ${ }^{19}$ In turn, this led to the development of Hasidic courts and eventually dynasties, some of which have resisted to this day. ${ }^{20}$ Most interesting, this movement which started as an offshoot of mainstream Judaism meant to solve a religious crisis by straying partially away from the established religious practices has nowadays ended up by being the most ultra-Orthodox form of Jewishness.

\section{Hesychasm and Hasidism}

A similar non-linear evolution can be seen in the case of Hesychasm. According to Steven Runciman, "the Hesychast doctrine, put forward by the monk Gregory Palamas [1269-1359], was that the true mystic could in the end see God, not in His

15 Caroline Finkel, Osman's Dream: The Story of the Ottoman Empire 1300-1923 (New York: Basic Books, 2007), 346.

16 Kaplan, Meditation and Kabbalah, 269.

17 Felicia Waldman, Ocultarea în mistica iudaică (Bucharest: Paideia, 2002), 173.

18 Mircea Eliade, A History of Religious Ideas from Muhammad to the Age of Reforms vol.3 (Chicago - London: University of Chicago Press, 1988), 178.

19 Waldman, Ocultarea în mistica iudaică, 173.

20 For more on Hasidic dynasties see Marcin Wodziński, Historical Atlas of Hasidism (Princeton - Oxford: Princeton University Press, 2018), 60. 
essence but in His energies, that is to say, His uncreated light. The doctrine was challenged by a Calabrian-born scholar, Barlaam, who made fun of the Hesychasts on the ground that they recommended as an exercise in concentration that one should stare at one's navel. This resulted in the very bitter religious controversy called "the Hesychast controversy," which took some time but was eventually resolved in Palamas' favor, with the victory of monasticism over philosophy, seen as "secular wisdom." (Incidentally, according to an account related by John Meyendorff, Palamas was captured by the Turks in 1354, in the aftermath of the earthquake that allowed them to conquer Gallipoli, and taken to Sultan Orhan's palace, which was located in the mountains between Bursa and Nicaea. There he seems to have had a very interesting theological discussion with the Sultan's son but refused to talk to a group of "Chiones," whom he understood to be Jewish converts to Islam..$^{22}$ ) Among other places, Hesychasm took strong roots in Bucovina, a region that welcomed many religious novelties along the time.

The fact that Baal Shem Tov was born in Bucovina is not only mentioned in several sources, ${ }^{23}$ but also supported by local legends. Besides the stories about the long time he spent in mediation in a cave in the Carpathian Mountains,$^{24}$ there is a particular legend about his praying in the synagogue of a small Moldovan town called Piatra Neamtz, an ancient citadel revived in the $15^{\text {th }}$ century, when Prince Stephen the Great (ca 1438-1504) established a Princely Court there. ${ }^{25}$ According to this legend, Baal Shem Tov would pray in this synagogue every time he came down from the mountains. The original stone building, dating from the $17^{\text {th }}$ century or even earlier, where Israel ben Eliezer is said to have prayed, appears to have deteriorated by mid- $18^{\text {th }}$ century and had to be replaced. We know this because in 1766 the local Jews obtained permission to build a new one, but in keeping with the Moldovan laws of the time they were no longer allowed to use stone, so they erected the wooden construction that has survived unto this day ${ }^{26}$ Called "Baal Shem Tov," this wooden synagogue is now the main attraction of the area, as it is one of the oldest wooden synagogues in Europe and the only one fully preserved in its original form, including the nails and bolts, which has earned it a place on the UNESCO monuments list. ${ }^{27}$ According to the oral tradition, Baal Shem Tov always sat on chair number 9 , which is why until the $20^{\text {th }}$ century nobody was allowed to

21 Steven Runciman, the Byzantine Theocracy (Cambridge: Cambridge University Press, 1977), 155-156.

22 John Meyerdorff, Byzantine Hesychasm, Historical, Theological and Social Problems (London: Variorum Reprints, 1974), 212-213.

23 See note 3 above.

24 See Idel, "R. Israel Ba'al Shem Tov 'In the State of Walachia” 79.

25 Piatra Neamty City App, “Curtea Domneascâ Din Piatra-Neamt” (Accessed 23 December 2020).

${ }^{26}$ See Radio România International, "The Baal Shem Tov Synagogue in Piatra Neamt” (Accessed 20 December 2020). Also Josef Kaufman, Cronica Comunităților Israelite din Județul Neamț (Piatra Neamț: Record, 1928-1929), XIII.

27 See 15 Românian Synagogues, "Piatra Neamty/ Baal Shem Tov” (Accessed 18 December 2020). 
use it. ${ }^{28}$ Like other Jewish places of worship of the time, the "Baal Shem Tov' synagogue is built below the earth level, so that it could be grandiose without exceeding in exterior height the surrounding church buildings. Besides the usual main hall and women's gallery, the construction includes a small special section for children, which is rather rare. Crafted in wood blown with gold and bronze in 1835, the Eastern wall three layered Aron Kodesh, which contains the Torah scrolls, is a work or art in itself. $^{29}$ Today the building hosts the Museum of the Jewish Community of Piatra Neamtz.

The connection between Baal Shem Tov and the Moldovan Carpathians is also important because it helps explain the specificity of one key aspect of his early practices: a certain type of asceticism that was characteristic of this geographical area. There are two versions of the best-known collection of Hasidic hagiography on the life and deeds of Baal Shem Tov, one in Hebrew and one in Yiddish. ${ }^{30}$ Although they are slightly divergent, they both describe his habit of withdrawing regularly into the mountains, where he used to take one loaf of bread for one meal and eat once a week, a habit he continued for a number of years. While asceticism in itself is not new to Jewish mysticism (various legends attribute a similar attitude to Isaac Luria, for instance), it does not usually exceed weeks or months. As Moshe Idel points out, "the practice of living in solitude in a cave found in a mountain for a long time has no antecedent in the long Jewish tradition of hitbodedut (spiritual solitude)." 31

\section{Moreover,}

"The combination of mountain seclusion and an ascetic exercise that involves consuming only bread is also known from hesychastic asceticism. A mystical practice that consists in techniques for reaching experiences of calmness (Hesychia) and communion with God when performed in a state of seclusion, hesychastic asceticism crystallized in the mid-fourteenth century in Mt. Athos (although it drew upon much earlier sources) and slowly spread into the Balkans and the northern part of Romania, especially the Carpathian Mountains." 32

What is important to note in this context is that unlike Russian and Greek hesychastic asceticism, which are harsh, the Romanian one, although faithful to

28 Andreea Ghită, "Hanuka 5570, la sinagoga veche-nouă de la Piatra Neamț”, Acum (Accessed 20 December 2009).

29 More in Aristide Streja- Lucian Schwarz, The Synagogue in Romania (Bucharest: Hasefer, 2009), 152.

30 The Hebrew one was published in English: Dan Ben-Amos-Jerome R. Mintz (eds.), "In Praise of the Ba'al Shem Tov" (New York: Schocken Books, 1984).

31 Idel, "R. Israel Ba'al Shem Tov 'In the State of Walachia”, 81.

32 Idel, “R. Israel Ba'al Shem Tov 'In the State of Walachia”, 79. 
the apostolic model, is, as Vasile Andru calls it, "moderate," ${ }^{33}$ and therefore befitting to Baal Shem Tov's more worldly inclination. Thus, he "seems to have engaged in a practice that was widespread among the ascetic Orthodox monks in the Carpathians for some few centuries, before changing over to a non-ascetic religiosity during a later stage." 34

There is a particularly interesting similarity between the life and religious practices of Baal Shem Tov and those of a certain Christian Orthodox monk, Abbot Vasile, from the monastery of Poiana Mărului, who lived at exactly the same time (1700-1766) in the same geographical area (Neamtz). ${ }^{35}$ It seems that while on the one hand they both insisted on the centrality of prayer in the religious experience, on the other hand, just like Baal Shem Tov attempted to simplify the complicated Lurianic system, especially in regard to the mystical intentions (kavvanot), so did Vasile try to simplify the complex hesychastic practice of the prayer of Jesus into a more accessible version, which was later adopted by many Romanian and even Russian ascetics. ${ }^{36}$ Moreover, both men represented "new forms of religious leadership, a novel gravitation around living personalities who were central to the social economy of the two mystical movements." ${ }^{37}$ Not last and not in the least, while most elements related to the notion of holy man predated both eighteenth century Jewish mysticism and hesychasm, the structural similarity of their place in each respective movement is striking. ${ }^{38}$

\section{Sufism and Hasidism}

It is clear (and natural) that the early Hasidic masters were exposed to more than one cultural and religious context, from which they were not shy to borrow various elements. Rabbi Moshe Hayyim Efrayyim of Sudylkov (1748-1800), Baal Shem Tov's grandson, relates that the founder of Hasidism easily resorted to stories of a non-Jewish extraction, to which his immediate followers showed in their turn a large degree of openness. ${ }^{39}$ Here it is interesting to note that, besides the obvious connection between Hasidism and the Ottoman Sabbatean movement, as well as the legend concerning his father's abduction by the Tatars, both mentioned earlier, there are several accounts of Baal Shem Tov's own encounters with Muslims in

33 Vasile Andru, Isihasmul sau meșteșugul inimii (Bucharest: Herald, 2011), 15.

34 Idel, “R. Israel Ba'al Shem Tov 'In the State of Walachia”, 81.

35 For more details see Ion Marian Croitoru, "Saint Basil of Poiana Mărului. Biographic milestones", Icoana Credinței 3/6 (2017), 92-105.

36 Dario Raccanello, Rugăciunea lui Iisus în scrierile Starețului Vasile de la Poiana Mărului (Sibiu: Deisis, 1996), 175, 234.

37 Idel, "R. Israel Ba'al Shem Tov 'In the State of Walachia”, 88.

38 Igor Tourov, "Hasidism and Christianity of the Eastern Territory of the Polish-Lithuanian Commonwealth: Possible Contacts and Mutual Influences," Kabbalah 10 (2004), 89-97.

39 Idel, "R. Israel Ba'al Shem Tov 'In the State of Walachia”, 77. 
various settings, including some with merchants, on market days, in Balta, a town on the Podolia-Moldova border during the early eighteenth century, ${ }^{40}$ but also in Istanbul, where he seems to have spent a year in the course of a failed attempt to go to the Holy Land. ${ }^{41}$ Although except for a few legends on the miracles he worked there, no reliable biographical information is available on what he did in the Ottoman capital, it can be safely inferred that having spent so much time in the city he must have come in contact with various forms of Sufism. Furthermore, considering that one of the crucial traits of Hasidism from its very beginning was the resort to storytelling as a medium for transmitting religious messages, the influence of some elements of Turkish folklore, such as the widespread stories related to Nasreddin Hodja, which abound in the area unto this day, should not be overlooked.

This, however, is not all. Evidently, as Moshe Idel underlines, "in addition to possible influences of contemporary Muslim material on the nascent Hasidism, there are also earlier Sufi and other types of materials stemming from Muslim sources that nourished the Jewish sources of early Hasidism." 42

Indeed, as Tom Block remarks in his turn,

"[...] the migration of teaching tales originally told of Sufi masters around the Mediterranean, Middle East and Arabia in the eighth-fifteenth centuries, into the Jewish spiritual stream from the time of Moses Maimonides ( $12^{\text {th }}$ century) through European Hasidism in the $18^{\text {th }}$ and $19^{\text {th }}$ centuries. These shared tales further highlight the strong connection between Jewish and Islamic spirituality, and the specific manner in which the one (Sufism) affected the other (Hasidism)." ${ }^{43}$

Block identifies and analyzes several such themes. Talking, for instance, about the "hidden saints," a topic equally important in both Sufism and Hasidism, he exemplifies his point with "a story told about the Hasidic Rabbi Elimelekh of Lyzhansk [1717-1787]; "melekh" means "king" in Hebrew)" that "clearly originated with an earlier Sufi source, being traced back to Abdul-Qadir Gilani [1078-1166], the founder of the Qadiriyya Sufi lineage," ${ }^{44}$ which leads him to conclude that the

"two stories are strong testament to the intertwining of the Jewish and Islamic mystical streams, where the influence of ancient Jewish mysticism

40 Dan Ben Amos - Jerome R. Mintz (eds.), In Praise of the Ba'al Shem Tov (New York: Schocken Books, 1984), 59.

41 Dan Ben Amos - Jerome R. Mintz (eds.), In Praise of the Ba'al Shem Tov, 237.

42 Idel, "R. Israel Ba'al Shem Tov 'In the State of Walachia”, 96.

43 Tom Block, "Sufism and Hasidism: Shared Spiritual Tales", Sophia: The Journal of Traditional Studies (October 2011) (Accessed 2 January 2021).

44 Block, "Sufism and Hasidism: Shared Spiritual Tales". 
might have touched the development of Sufism - and then Islamic mysticism re-introduced these ideas to later Jewish thinkers!" 45

Another theme that he identifies in both traditions concerns the impermanence of this world, the notion that "this too shall pass," which Block exemplifies with "a tale attributed to King Solomon (c. 950 B.C.E.)," that can actually "be traced to Sufis sources, and specifically Farid ad-Din Attar [1142-1221]," as "Rabbi Michael Bernstein noted in the Philadelphia Jewish Voice (March 2008)." ${ }^{46}$

Furthermore, he finds that both types of mysticism share the belief that one must be involved in life, and that social action should be a central aspect of spiritual practice. This idea can be traced back to a Sufi story about Dhul Nun alMisri (796-860) and subsequently to a Hasidic legend about Rabbi Nachman of Breslov (1772-1810). Thus,

"For Sufis and subsequently Jewish practitioners, one could not simply remove oneself from society and live in a contemplative state, concentrating only on one's personal relationship with God. One vital aspect of mystical appreciation stems from interaction with the world as it is, with finding God in the everyday moment and with alleviating the pain of others." ${ }^{27}$

The very similar meanings of the notions of Tzaddik and Sheikh are yet another proof of the interconnection between the two traditions, as are the common ideas about morality and true worship. "There are," Block adds, "further instances of Hasidic tales that show the clear influence of Sufi teachings, though an exact Sufi match has not yet been found," which is not surprising because "acts that would have been considered sins in mainstream Judaism or Islam took on esoteric meaning for both spiritual paths." 48

Martin Buber himself gives such an example in his own book on Hasidism, ${ }^{49}$ where he speaks of a story about Rabbi Aaron of Karlin, a favorite disciple of the Maggid of Mesritch (Rabbi Dov Ber, also known as Dob Baer ben Samuel, the son-inlaw of Rabbi Alexander the Shochet, who had been Baal Shem Tov's scribe for eight years). The story goes that:

"A fellow disciple, returning home from Mesritch, came about midnight to Karlin, and desired to greet his friend. He at once went to his house, and

${ }_{45}$ Block, "Sufism and Hasidism: Shared Spiritual Tales". The case in point is "number " 36 " - referring to the number of days traveled by the hidden Islamic saints with the "pious" sheikhs," which is "the exact number of hidden, righteous men that the Talmudic [...] masters claimed wandered the earth at all times."

46 Block, "Sufism and Hasidism: Shared Spiritual Tales".

47 Block, "Sufism and Hasidism: Shared Spiritual Tales".

48 Block, "Sufism and Hasidism: Shared Spiritual Tales".

49 Martin Buber, Hasidism (New York: The Philosophical Library, 1948), 185. 
knocked on the lighted window. "Who are you?" asked a voice from within, and, certain that Rabbi Aaron would recognize his voice, he answered, "I." No reply came, and the door was not opened, although he knocked again and again. At last he cried, "Aaron, why do you not open to me?" Then he heard from within, "Who is it who is so bold to say 'I,' as God alone may do?" He said in his heart, "I have not Yet learned my lesson," and returned immediately to the Maggid." 50

The account can be traced back to the first part of Jalaluddin Rumi's collection of Sufi mystic parables "Mesnevi," and reflects both traditions' negation of the importance of the ego, (bittul ha-yesh: "annihilation of somethingness" for Hasidim or fana: "annihilation" for Sufis), which only became part of mainstream Judaism after the $12^{\text {th }}$ century. ${ }^{51}$

Still, the connection between Sufism and Hasidism is even clearer in their similar view of the ecstatic mystical experience, although this link can indeed be seen even further back, in the $13^{\text {th }}$ century interplay between Sufi and Kabbalistic practices, especially, though by no means exclusively, in the works of Abraham Abulafia (1240 - ca 1291). As Moshe Idel explains, speaking of a parable which apparently reached $\mathrm{R}$. Yizhaq of Acre $\left(13^{\text {th }}-14^{\text {th }}\right.$ century) from a Sufi source, in this case

"the occurrence of philosophical terms, the ideal of devequt, ${ }^{52}$ the issue of hitbodedut as mental concentration, as well as Sufi elements like the contemplation of beauty as a mystical technique, point to a synthesis between Sufi and other ecstatic types of mysticism." 53

Indeed, while "a new language of religious experience was taking hold in medieval Islam," with "philosophers and Sufi mystics, legal scholars, theologians, and poets" seeking to "capture the experiential dimension of religious life" and " reinventing Islamic vocabulary to do so," ${ }^{4}$ as Diana Lobel notes, important Jewish thinkers like Judah Ha-Levi (1075-1141) adapted and transformed "this new language of inner experience to fit the Jewish context," presenting "classical Judaism using the new experiential language emerging in medieval Islam" and describing "unique Jewish experiences with vocabulary from the wider Islamic

50 Buber, Hasidism, 185.

51 Though according to Tom Block, "it most probably did not originate with him, initially being related about the ecstatic Sufi Mansur al-Hallaj (d. 922)” Block, "Sufism and Hasidism: Shared Spiritual Tales".

52 Devequt (in Hebrew) means "clinging to God."

53 Idel, Hasidism between Ecstasy and Magic, 62.

54 Diana Lobel, Between Mysticism and Philosophy. Sufi Language of Religious Experience in Judah Ha-Levi's Kuzari (Albany: State University of New York Press, 2000), 1. 
culture, using language which would capture the imagination of his contemporaries." ${ }^{55}$

The type of mysticism resulting from this influence also includes the use of music and dance, both of biblical extract (see the stories related to King David, for instance, or the tradition of dancing for Purim and at weddings), but which became widespread in kabbalistic mystical endeavors particularly under Sufi influence. The Hasidim laid a particular emphasis on bodily movements and gestures during their prayer because

\begin{abstract}
"Dance creates drama, releases emotions, and can lead to new states of consciousness. It is perhaps the most embodied form of spirituality, as we find, for example, in Sufi devotional practice [...] As part of their creations of new rituals, the Kabbalists of Safed would greet the Sabbath with singing and dancing, and Isaac Luria was known to celebrate the holiday of Simchat Torah with much more extreme physical enthusiasm than his predecessors. As the heirs of the Safed customs, Hasidism developed dance into a sacred form of worship beyond the context of holidays or at weddings." 56
\end{abstract}

\title{
4. Hesychasm and Sufism
}

Obviously, besides their relation to Hasidism, a relation can also be traced between Sufism and Hesychasm themselves. In an article published in the "Greek Orthodox Theological Review" in 1986, ${ }^{57}$ Seyyed Hossein Nasr draws a very interesting parallel between the Prayer of the Heart in the two mystical traditions, underlining the remarkable similarity between them in this regard, which, as he puts it,

"is due not to historical borrowings but to the nature of Christian and Islamic spirituality on the one hand and the constitution of the human microcosm on the other. The prayer which revives the heart does so not as a result of historical influences but because of the grace that emanates from a revelation. Likewise, the heart is quickened and brought to life by this grace because it is the locus of the divine Presence and the center of the microcosm which relates it to higher levels of reality." 58

Nasr analyzes in great detail the resemblance between such practices as the remembrance and invocation of the name of God and the continuity of prayer as

55 Lobel, Between Mysticism and Philosophy. Sufi Language of Religious Experience in Judah Ha-Levi's Kuzari, 1.

56 David Biale vd., Hasidism: A New History (Princeton - Oxford: Princeton University Press, 2018), 217218.

57 Seyyed Hossein Nasr, "The Prayer of the Heart in Hesychasm and Sufism”, Greek Orthodox Theological Review 31/1-2 (1986), 195-203.

58 Nasr, "The Prayer of the Heart in Hesychasm and Sufism", 196. 
central methods of spiritual realization (although in Sufi writings they are usually less directly addressed than in the Philokalia, ${ }^{59}$ for instance, being mostly hinted at), as well as the shared view that the practice of the incantation method (which "can in fact be summarized as putting oneself in the Name and putting the Name in the heart") 60 "must be based upon the guidance of a teacher and master" and should be "accompanied by appropriate instruction concerning meditation, the practice of virtue and other elements of the spiritual life," ${ }^{61}$ considering that in both cases the mystical experience involves contemplation as well as action, ${ }^{62}$ including breathing techniques. ${ }^{63}$ (In fact, as Moshe Idel remarks, "discussions of breathing appear in Yoga, in Sufism and in Hesychasm, albeit with different emphases," but they can also be found in the Jewish mystical practice of Abraham Abulafia, whose writings "contain brief statements about and allusions to a technique of breathing to be practiced by one who pronounces the Ineffable Name," under demonstrated Sufi influence. ${ }^{64}$

Indeed, while Sufism is "subjectively speaking [...] 'heart-wakefulness'," 65 "the Hesychast tradition of the Orthodox Church, for its part, speaks repeatedly of 'prayer of the heart,' of the 'discovery of the place of the heart,' of the 'descent from the head to the heart,' and of the 'union of the intellect (nous) with the

59 As G. E. H. Palmer, Philip Sherrard and Archimandrite Kallistos Ware explain in their Introduction to the first volume of their translation of the Philokalia from Greek, "The Philokalia is a collection of texts written between the fourth and the fifteenth centuries by spiritual masters of the Orthodox Christian tradition. It was compiled in the eighteenth century by two Greek monks, St Nikodimos of the Holy Mountain of Athas (1749-1809) and St Makarios of Corinth (1731-1805), and was first published at Venice in 1782" [G. E. H. Palmer vd. (ed.), The Philokalia, The Complete Text compiled by St. Nikodimos of the Holy Mountain and St. Makarios of Corinth, (London- Boston: Faber and Faber, 1979), 11.]

60 G. E. H. Palmer vd. (ed.), The Philokalia, The Complete Text compiled by St. Nikodimos of the Holy Mountain and St. Makarios of Corinth, 200.

61 G. E. H. Palmer vd. (ed.), The Philokalia, The Complete Text compiled by St. Nikodimos of the Holy Mountain and St. Makarios of Corinth, 198.

62 G. E. H. Palmer vd. (ed.), The Philokalia, The Complete Text compiled by St. Nikodimos of the Holy Mountain and St. Makarios of Corinth , 199.

63 G. E. H. Palmer vd. (ed.), The Philokalia, The Complete Text compiled by St. Nikodimos of the Holy Mountain and St. Makarios of Corinth, 200.

64 Moshe Idel, The Mystical Experience in Abraham Abulafia (Albany: State University of New York Press,1988), 24.

65 Martin Lings, What is Sufism? (London: George Allen \& Unwin, 1975), 48-49. 
heart." ${ }^{66}$ In fact, "both the Hesychast and the Sufi aim at union or knowledge of God beyond all concepts," ${ }^{67}$ just like the Hasid.

In this context of "active" mysticism (which is clearly the case of Hasidism as well, especially in its later stages), and given our particular interest in the Moldovan/Wallachian connection, we should perhaps also remember the movement initiated by Badr al-Din (1358-1419), a native of Simavna (a town near Adrianople [today Edirne] in Thrace), a Saljuq on his father's side, and a Christian on his mother's, who decided, after spending some time in the Middle East, particularly in Egypt, where he was heavily influenced by the mysticism of Ibn al'Arabi, to become associated with Mircea the Elder (c. 1355 - 31 January 1418), the Prince of Wallachia (from 1386 until his death in 1418), which explains why the movement extended as far as Deli Orman, currently Teleorman, a district in Southern Wallachia. ${ }^{68}$ History records that Badr al-Din initiated a session of SufiHesychastic joint prayers in the Greek island of Chios, much on the grounds described by Nasr, laying the foundations for the a future comparison between the two traditions. He was later martyred by the Ottomans, but apparently his legacy endured. ${ }^{69}$

This brings us back to the matter of Romanian hesychasm which, unlike the harsher Greek and Russian ones, is characterized by what Vasile Andru has called "a sense of moderation and avoidance of the extremes (which are thereby cancelled)." ${ }^{70}$ Here the aim of the mystical experience is

"not the obsession of illumination, but an improved life. This is not a matter of terminology, but of attitude. Illumination is nothing other than the quantitative, visible aspect of improvement. Illumination is not an aim in itself, but a pre-requisite for improvement, for redemption. The ideal of Romanian asceticism has always been a man with an improved life. This ideal provides good guidance not only to the hesychia, but also to worldly existence. It connects religion to life. Hesychasm is thus experienced in daily living." ${ }^{11}$

${ }^{66}$ Kallistos Ware, "How Do We Enter the Heart?", Paths to the Heart Sufism and the Christian East, ed. James S. Cutsinger (World Wisdom, 2004), 5.

67 Gray Henry, "St Seraphim of Sarov in Sufic Perspective", Paths to the Heart Sufism and the Christian East, ed. James S. Cutsinger (World Wisdom, 2004), 27.

68 H. T. Norris, Popular Sufism in Eastern Europe. Sufi brotherhoods and the dialogue with Christianity and 'Heterodoxy' (London - New York: Routledge, 2006), 49.

${ }^{69}$ Norris, Popular Sufism in Eastern Europe. Sufi brotherhoods and the dialogue with Christianity and 'Heterodoxy, 49.

70 Andru, Isihasmul sau meșteșugul inimii, 15.

71 Andru, Isihasmul sau meșteșugul inimii, 15-16. 
This very specific outlook, with its worldly orientation that goes beyond the tranquility and inner stillness implied by hesychia in its usual acceptance (without, however, losing its sense of divine presence), must have certainly born an influence on the emerging ideas of Baal Shem Tov, who seems to have come in direct contact with it, as he did with some of the Sufi ideas of his time.

\section{Conclusion}

This incursion into the background against which Hasidism emerged in a border area (in all senses of the word, from mystical to geographical) has revealed the intricate web of interactions and subsequent influences that all three monotheistic religions underwent in this particular place at the beginning of the $18^{\text {th }}$ century, fed by previous evolutions and leading to new spiritual outlooks. There are, to be sure, other connections that could be followed in order to understand the source of some of the magical Hasidic practices, such as that with the shamanic rituals of the Csángós, a population of Hungarian extraction living in several villages in the subCarpathian region of Northern Moldova since the mid-thirteenth, or the Hutzuls, a Slavic population living, inter alia, in the southern Ukrainian Carpathians and the Northern Romanian ones, and which adopted some Romanian customs, ${ }^{72}$ but they exceed the scope of this study.

Whereas it is generally possible to track the transmission of ideas from one place to another and from a generation to the next, there are instances when it is not at all clear who influenced who. While Tom Block speaks of "the intertwining of the Jewish and Islamic mystical streams, where the influence of ancient Jewish mysticism might have touched the development of Sufism - and then Islamic mysticism re-introduced these ideas to later Jewish thinkers, ${ }^{73}$ Kallistos Ware wonders "has Sufism influenced Hesychasm, or vice-versa? Or was the influence mutual? Here is a challenging area for future research." 74

Looking at Hasidism as a meeting point between Sufi and Hesychastic ideas, through the lens of the various influences its founder could have undergone based on both his spiritual legacy and occasional encounters, and, naturally, at some notions clearly identifiable in all the three traditions, has allowed us to see possible avenues of further analysis but also new questions arising.

Not last and not in the least, Hasidism's capacity to pass from a marginal position to a mainstream one and from a movement based on straying away from the established ritual to an ultra-orthodox status shows its adaptive ability and invites to more extensive scrutiny.

\footnotetext{
72 Idel, “R. Israel Ba'al Shem Tov 'In the State of Walachia”, 98.

73 Block, "Sufism and Hasidism: Shared Spiritual Tales".

74 Ware, "How Do We Enter the Heart?", 20.
} 
Conflict of Interest / Çıkar Çatışması: The author declared that there is no conflict of interest. / Yazar çıkar çatışması olmadığını beyan etmiştir.

Grant Support / Finansal Destek: The author declared that this study has received no financial support. / Yazar bu çalışma için finansal destek almadığını beyan etmiştir.

\section{Bibliography:}

Andru, Vasile. Isihasmul sau meșteșugul inimii. Bucharest: Herald, 2011.

Ben-Amos, Dan and Jerome R. Mintz (eds.). In Praise of the Ba'al Shem Tov. New York: Schocken Books,1984.

Biale, David vd. Hasidism, A New History. Princeton - Oxford: Princeton University Press, 2018.

Block, Tom. Shalom Salaam: A Story of a Mystical Fraternity. Louisville: Fons Vitae, 2011.

Block, Tom, "Sufism and Hasidism: Shared Spiritual Tales". Sophia: The Journal of Traditional Studies (October 2011). Accessed 2 January 2021. http://www.tomblock.com/writing/sufism-and-hasidism-shared-spiritualtales-0

Brady, David. 1666, The Year of the Beast. Manchester: John Rylands University Library of Manchester, 1979.

Buber, Martin. Hasidism. New York: The Philosophical Library, 1948.

Croitoru, Ion Marian. "Saint Basil of Poiana Mărului. Biographic milestones”. Icoana Credinței 3/6 (2017), 92-105.

Eliade, Mircea. A History of Religious Ideas vol. 3 From Muhammad to the Age of Reforms. Chicago - London: University of Chicago Press, 1988.

Finkel, Caroline. Osman's Dream: The Story of the Ottoman Empire 1300-1923. New York: Basic Books, 2007.

Ghită, Andreea. "Hanuka 5570, la sinagoga veche-nouă de la Piatra Neamț”. Acum. Accessed 20 December 2009. http://www.acum.tv/articol/10800/. 
Henry, Gray. "St Seraphim of Sarov in Sufic Perspective". Paths to the Heart Sufism and the Christian East. Ed. James S. Cutsinger. 24-31. World Wisdom, 2004.

Idel, Moshe. Hasidism between Ecstasy and Magic. Albany: State University of New York Press, 1995.

Idel, Moshe. "In the State of Walachia Near the Border - Or Was the Besht Born in Okopy?”. Eurolimes 5 (2008), 14-20.

Idel, Moshe. "R. Israel Ba'al Shem Tov 'In the State of Walachia”. Holy Dissent, Jewish and Christian Mystics in Eastern Europe. Ed. Glenn Dynner. 69-103. Detroit: Wayne State University Press, 2011.

Idel, Moshe. The Mystical Experience in Abraham Abulafia. Albany: State University of New York Press, 1988.

Kaplan, Aryeh. Mediation and Kabbalah. Boston: WeiserBooks, 1985.

Kaufman, Josef. Cronica Comunităților Israelite din Județul Neamț. Piatra Neamț: Record, 1928-1929.

Levin, Meyer. The Golden Mountain, Marvelous Tales of Rabbi Israel Baal Shem and of his Great-grandson, Rabbi Nachman, Retold from Hebrew, Yiddish and German Sources. New York: Jonathan Cape \& Robert Ballou, 1932.

Lings, Martin. What is Sufism?. London: George Allen \& Unwin, 1975.

Lobel, Diana. Between Mysticism and Philosophy Sufi Language of Religious Experience in Judah Ha-Levi's Kuzari. Albany: State University of New York Press, 2000.

Magid, Shaul. Hasidism Incarnate, Hasidism, Christianity and the Construction of Modern Judaism. Standford: Stanford University Press, 2015.

Meyerdorff, John. Byzantine Hesychasm, Historical, Theological and Social Problems. London: Variorum Reprints, 1974.

Nasr, Seyyed Hossein. "The Prayer of the Heart in Hesychasm and Sufism”. Greek Orthodox Theological Review 31/ 1-2 (1986), 195-203.

Norris, H. T. Popular Sufism in Eastern Europe. Sufi brotherhoods and the dialogue with Christianity and 'Heterodoxy'. London - New York: Routledge, 2006.

Palmer, G. E. H. vd. (trans. and eds.) The Philokalia, The Complete Text compiled by St. Nikodimos of the Holy Mountain and St. Makarios of Corinth. London, Boston: Faber and Faber, 1979.

Pena, Cătălin. "Grozăviile ar fi albit părul pruncilor când moldovenii s-au schimbat toți în tâlhari răzvrătiți". Evenimentul Istoric. Accessed 9 July 2020. https://evenimentulistoric.ro/grozaviile-ar-fi-albit-parul-pruncilor-candmoldovenii-s-au-schimbat-toti-in-talhari-razvratiti.html/2 
Piatra Nemty City App. "Curtea Domneascâ Din Piatra-Neamt". Accessed 23 December 2020. https://piatraneamtcity.ro/places/curtea-domneasca-dinpiatra-neamt-xxbbwctt28gooq

Raccanello, Dario. Rugăciunea lui Iisus în scrierile Starețului Vasile de la Poiana Mărului. Sibiu: Deisis, 1996.

Radio România International. "The Baal Shem Tov Synagogue in Piatra Neamt". $\begin{array}{llll}\text { Accessed } & 20 & \text { December } & 2020\end{array}$ https://www.rri.ro/en_gb/the_baal_shem_tov_synagogue_in_piatra_neamt2539521

Runciman, Steven. The Byzantine Theocracy. Cambridge: Cambridge University Press, 1977.

Scholem, Gershom. Major Trends in Jewish Mysticism. New York: Schocken Books, 1995.

Scholem, Gershom. On the Kabbalah and its Symbolism. New York: Schocken Books, 1965.

Streja, Aristide - Schwarz, Lucian. The Synagogue in Romania. Bucharest: Hasefer, 2. Ed. 2009.

Tourov, Igor. "Hasidism and Christianity of the Eastern Territory of the PolishLithuanian Commonwealth: Possible Contacts and Mutual Influences". Kabbalah 10 (2004), 89-97.

Waldman, Felicia. Ocultarea în mistica iudaică .Bucharest: Paideia, 2002.

Ware, Kallistos. "How Do We Enter the Heart?". Paths to the Heart Sufism and the Christian East. Ed. James S. Cutsinger. 2-23. World Wisdom, 2004.

Wodziński, Marcin. Historical Atlas of Hasidism. Princeton - Oxford: Princeton University Press 2018.

15 Românian Synagogues. "Piatra Neamty/Baal Shem Tov". Accessed 18 December 2020. http://www.romanian-synagogues.org/piatra-neamt\#/fact-sheet-23 


\title{
Tasavvuf ve Hesikazm'in Etkisinde Hasidizm: Baal Shem Tov - Bir Yahudi Sufi midir yoksa Hesikast mıdır?
}

\begin{abstract}
Özet
Çeşitli efsanelere ve belgesel kanıtlara göre, İsrail Ben Eliezer, Kuzey Moldova'da Bukovina'da yoksulluğun, Yahudi topluluklarının kelimenin tam anlamıyla 'haham' istihdam etmeye ve erkek çocukların Bar Mitzvah'larına (reşit olma) hazırlık amacıyla bile Tevrat'ı öğrenmeleri için okullar, "hederler" düzenlemeye yönelik mali imkanlardan yoksun oldukları bir noktaya ulaştığı küçük bir kasabada doğdu ve çocukluğunu orada geçirdi. Bu vahim şartlarda Israel ben Eliezer sağlıklı bir çözüm buldu: Tanrı'ya yaklaşmak için Talmud'u kapsamlı bir şekilde çalışmaya gerek olmadığını savundu; kişi sadece O'nu her şeyde görerek ve dua yoluyla ve aynı zamanda şarkı, dans ve hikaye anlatımı yoluyla basit ve samimi bir adanmışlık uygulayarak Tanrı'ya ibadet edebilirdi. Bu aynı zamanda, genellikle ilim ehli bir adam olan hahamın, öğüt verebilecek ve çevresindekileri toplayabilecek doğru ve bilge bir 'tsaddik' ile yer değiştirmesi anlamına geliyordu. $\mathrm{Bu}$, İsrail ben Eliezer'e Baal Shem Tov'un (ismi güzel efendi) lakabını kazandırdı. Fikirleri, görünüşte bilgili olduğu Luryanizm ve Sabatayizm gibi önceki Yahudi mistik eğilimlerinin doğal bir devamı olarak ortaya çıkmış, ancak bu düşünceler aynı zamanda bölgede gelişen ve doğrudan veya dolaylı temas kurduğu diğer mistisizm türlerinden de etkilenmiş gibi görünüyordu. Böylelikle, yerel bir sinagoga yaptığı ziyaretlerle ilgili bir efsaneyle desteklenen Moldova Karpatlar'daki varlığı, ilk zamanlardaki uygulamalarının (daha sonra vazgeçtiği) temel bir yönünün kendine mahsus oluşunu da açıklar: Bu coğrafyada yaygın "1lımlı" bir hesikazmın (sert Yunan ve Rus inzivalarının aksine) özelliği olan belirli bir 'çilecilik' türünü hayatında uygulamaya başlamıştı. Bu tür bir çilecilik, civardaki başkalarının yanı sıra, dünyevi yönelimi İsrail Ben Eliezer'in kendi eğilimlerine uygun olan ve yakındaki bir manastırda bir Başrahip Basil tarafından uygulanıyordu. Her ikisi de duanın merkeziyetinde israr ediyor ve "yeni dini liderlik biçimleriyle, iki mistik hareketin sosyal ekonomisinin merkezinde yer alan yaşayan örneklikleri etrafinda yeni bir çekim alanı oluşturarak" temsil ediyorlardı. Dahası, Baal Shem Tov, daha önce olduğundan çok daha fazla önem verdiği müzik ve dans gibi daha önceki Kabalistik ritüellerde mevcut olan Sufi unsurlara aşinalığının yanı sıra, Türklerin hatta (Nasreddin Hoca şakalarında mevcut) dini mesajlar verme yöntemi gibi folklorik hikayeler kullanma alışkanlığından da gözle görülür şekilde etkilenmişti. Torununun daha sonra ifade edeceği gibi Yahudi olmayan kaynaklardan ödünç almaktan çekinmemişti. Onun izinden giden müridanı, Rumi'nin eserlerinden hikayeler almıştı. Doğal olarak, Sufizm ve Hesikazm arasında, özellikle Tanrı'nın isimlerinin zikredilmesi ile duanın ruhsal gerçekleştirmenin merkezi yöntemleri olarak sürekliliği gibi uygulamalar arasındaki benzerlikte olduğu kadar, zikir pratiğinin, erdemli bir yaşayış ve manevi yaşamın diğer unsurları ile ilgili uygun bir
\end{abstract}


manevi rehberlik altında tecrübe edilmesi gerektiği, her iki durumda da mistik tecrübenin, tefekkür kadar eylemi de içerdiği görüşünde de benzerlikler mevcuttu. $\mathrm{Bu}$ "aktif" mistisizm formu bağlamında (özellikle daha sonraki aşamalarında Hasidizm'in durumu böyledir) bölgenin, mesela Hesikazm ile dinlerarası diyaloga meyilli Şeyh Bedreddin'in başlattığı tarikat gibi Sufi gruplara da ev sahipliği yaptığını hatırlamak önemlidir. Tüm bu etkiler altında, Baal Shem Tov'un fikirleri, Hasidi ailelerin ve nihayetinde bazıları bugüne kadar varlığını sürdürmüş hanedanların ortaya çıkmasına yol açmıştı. En ilginci, dini bir krizi yerleşik dini uygulamalardan kısmen uzaklaşarak çözmeyi amaçlayan ana akım Yahudiliğin bir dalı olarak başlayan bu hareket, günümüzde Yahudiliğin en ultra-Ortodoks formu haline gelmiştir. Son olarak, kurucusunun hem manevi mirasına hem de ara sıra karşılaşmalarına ve bazı fikirlere dayanarak geçirmiş olabileceği çeşitli etkilenmelerin merceğinden ve doğal olarak her üç geleneğin de hepsinde gözlemlenebilir ortak unsurlar üzerinden, Sufi ve Hesikastik fikirler arasinda bir buluşma noktası olarak Hasidizm'e bakıldığında, daha ileri incelemelerin yapilmasının mümkün olduğu anlaşılır.

Anahtar Kelimeler: Dinler Tarihi, Hasidilik, Tasavvuf, Hesikazm, Baal Shem Tov, Moldova, Bukovina. 